\title{
Dynamics of Climate Change Adaptations on Horticultural Land Use Practices around Mt. Kenya East Region
}

\author{
Kibetu Dickson Kinoti ${ }^{1}$, Colbert Mutiso Jackson ${ }^{2}$, Mwangi Joyce Muthoni ${ }^{3}$ \\ ${ }^{1}$ Department of Social Sciences, Chuka University, Chuka \\ ${ }^{2}$ Department of Humanities and Social Sciences, University of Eastern Africa Baraton, Eldoret, Kenya \\ ${ }^{3}$ Digital mapping Section, Galaxy Geo-Consultancy Services Inc, Embu, Kenya
}

Email address:

kinotikibetu@yahoo.com (K. D. Kinoti)

To cite this article:

Kibetu Dickson Kinoti, Colbert Mutiso Jackson, Mwangi Joyce Muthoni. Dynamics of Climate Change Adaptations on Horticultural Land Use Practices around Mt. Kenya East Region. American Journal of Environmental Protection. Vol. 7, No. 1, 2018, pp. 1-6. doi: 10.11648/j.ajep.20180701.11

Received: February 27, 2017; Accepted: April 13, 2017; Published: March 16, 2018

\begin{abstract}
Eastern slopes of Mount Kenya experienced widespread horticultural crop production after the establishment of Horticultural Crops Development Agency (HCDA) packing facilities within the region in the early 2000s. Favourable soils and climatic conditions triggered by growing export market demands have led to the changing patterns of agricultural land use practices in Mt. Kenya east region. The focus is now shifting to agro-diversification and land use intensification practices. The growing horticultural farming business in this region is impacting subsistence production, resource use as well as livelihood systems. This paper assesses the implications of climate change adaptation measures on household food security, gender roles and land management activities within the context of horticultural production land use practices. The findings ascertain that the region's increasing agro-diversification activities are both coping strategies to the climate related changes and the social, political as well as economic transformations ushered in by devolution.
\end{abstract}

Keywords: Agro-diversification, HCDA, Climate Change Adaptation, Horticultural Farming, Mt. Kenya East Region

\section{Introduction}

There is a need to raise land-based production to mitigate climate change related food shortage in Africa. This can be achieved through strategies such as; re-cultivation of abandoned lands, land use intensification and expansion into unproductive ecosystems [6], [19]. While agriculture remains the greatest driver of Kenya's economy, climate change and population pressure pose challenges to the full development of local agricultural systems. In most parts of Kenya, there is a widespread change of agricultural land use practices following erratic variations in climatic patterns, inconsistent food markets, increased costs of production and the collapse of most farmers' cooperative movements. This has resulted to abandonment of rain-fed crop farming in some areas to adoption of irrigated cropping, agricultural intensification and livelihood diversification strategies in other regions [23], [24], [26] and [34]. It has been discussed in many academic circles on the possibility of urbanisation and population growth likely to push the demand for agricultural products especially horticultural produce upwards [21], [25]. With the increasing rate of urbanisation in developing countries, informal produce markets are important source of food especially fresh fruits and vegetables consumed in many urban centers. In Kenya alone, over $90 \%$ of consumers buy fresh vegetables and fruits from informal open air markets compared to those who use formal supermarkets [28]. Locally the demand for Fresh Fruits and Vegetables in major urban centers has increased forcing growers to intensify production in their small farms to supply neighbouring towns [29].

A major challenge to the bridging of the arising food consumption gaps is the unavailability of arable land for expansion and the growing population density in rural agricultural areas of Kenya [27] and [33]. Related studies done in this region have looked at different aspects of horticultural production at different scales. For instance, a study by Wilkomm et al on analysis of land use change dynamics in Mt. Kenya region between 2010 to2015 showed 
different types of land uses do exist in this area and that cropland was increasing [36]. Another study on characterization of fresh fruits and vegetable transportation networks using road classification types by Dannerberg. $\mathrm{P}$ and G. Nduru in 2011 revealed that the region's spatial contiguity to Nairobi saw the average transportation time to Nairobi range between 3 to 4 hours [37. The study further retaliated on how the nature and quality of the road in the region influenced transport cost incurred in moving the horticultural products to the market, access to export market and business relevant information as well as the quality of horticultural products reaching Nairobi from the farms.

A research done by McCord, P. F., et al in 2015 on crop diversification among small holder famers near mount. Kenya showed increased diversification and intensification as a livelihood enhancement strategy by households towards becoming food and income sufficiency [35]. Van de Steeg et al in 2010 also carried out a study on characterisation of spatial distribution of farming systems in the Kenyan highlands and revealed how the spatial arrangement of farming system types was based on agro-ecological zoning [38] and [40]. Studies on impact of climate change adaptations on horticultural agro based land use practices in the region do not exist. By carrying out this study, dynamics of land use practices in the context of climate change adaptation on household food security, agricultural intensification, gender roles and land management activities amongst horticultural farmers will be examined.

\subsection{Selection of the Study Area}

Mt. Kenya East region is located between $36^{\circ} 45^{\prime} \mathrm{E}$ to $38^{\circ} 10^{\prime} \mathrm{E}$ and $0^{\circ} 50^{\prime} \mathrm{N}$ to $1^{\circ} 07^{\prime} \mathrm{S}$ within a very heterogeneous topography (fig. 1). The area is peculiar because the simple traditional agricultural food crop land use practices are evolving into complex urban and export-market oriented horticultural production. The region has a large number of small scale households engaging in horticulture on farm sizes usually less than 10 ha [32],[41]. This area has well developed transportation infrastructure, a fast growing population and favourable agro climatic conditions [39], [37]. Due to growing population and limited land for expansion, the region has experienced crop land use intensification and subdivisions. Global environmental challenges of climate change and decreasing soil fertility due to continuous cultivation are affecting land use management practices. In some instances, conversion of forests for agricultural and infrastructural use has occurred especially on the forest borderlines [42]. Eastern section of Mt. Kenya has different micro-climatic environments, abundant water resources and well drained fertile soils which make it a preferred horticultural production area in the country [5], [8], [20].

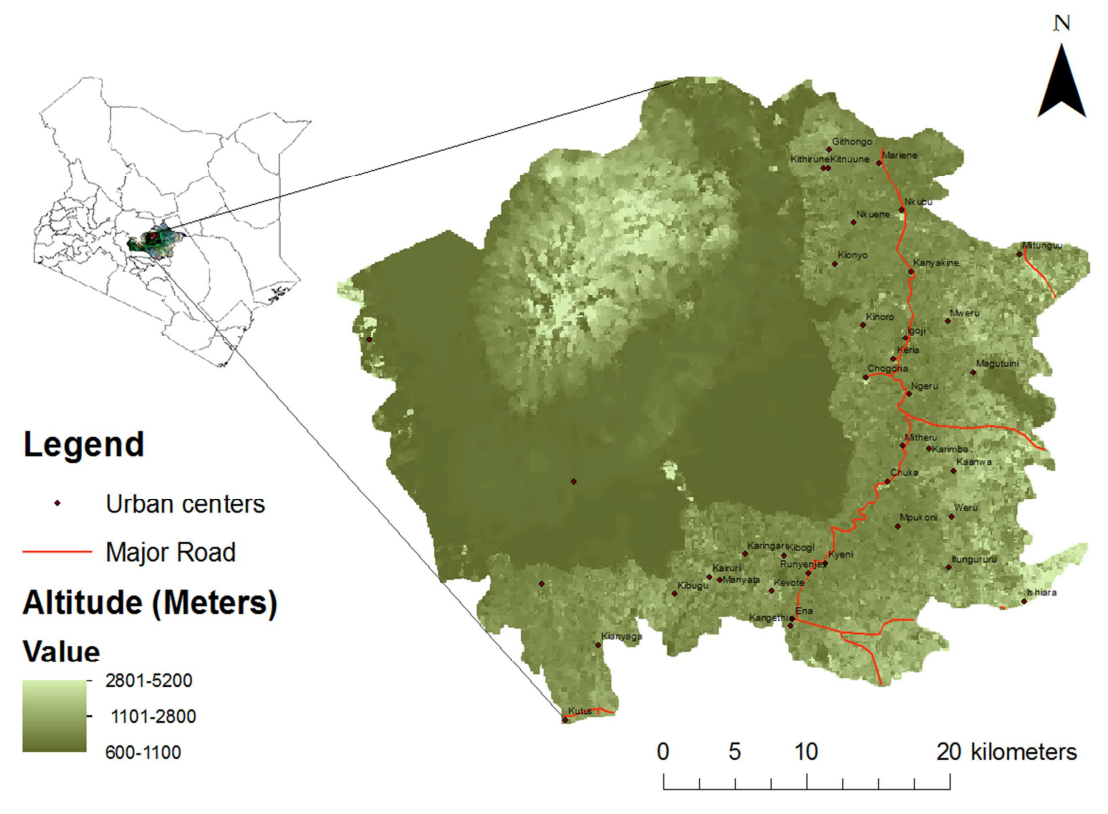

Figure 1. Study Area of Mt. Kenya East Region showing major roads and towns.

\subsection{Situational Analysis: Horticultural Land Use and Food Security}

Many small scale farmers in this region are engaging in various horticultural produce farming through contract farming for local supermarket or international export companies. Crop production is highly integrated with dairy cattle as a diversification strategy [43]. In Mt. Kenya East region population growth, economic development and land intensification have resulted to changes in land management practices [36], [38]. Observed variations cut across the region's diverse geographical and agro-ecological zones. An analysis of spatial patterns for agricultural land uses in this area is important for understanding household food security situation and natural resource use in the context of increased horticultural farming. Many studies have been done in this 
region on fresh fruits and vegetables value chain, Horticultural produce marketisation and transportation [12], [13], [14], [20]. Hither to little study has been done on the implications of climate change adaptations on horticultural farmers household food security needs their social networks, resource use as well as land management practices. Many small scale households around the eastern slopes of Mount Kenya are engaging in horticultural farming business which in itself is a big risk to the future of this region's food security. Notably, human activities are the most rapid driver of global change. In this particular case study the horticultural production is a key driver of local land use change in the region [18], [35]. If this proposition was used in understanding why Mount Kenya East remains a favourable region, then structural organisation, political inclinations, land use practices, efficient communication and transport systems would be singled out as contributing factors. The process of land use intensification experienced in this region is attributed to social, political and economic changes ushered in by the implementation of devolved governance in Kenya.

Amongst the rural societies, the impacts of population increase and global environmental changes such as climate change continue to impact on livelihoods and agricultural activities. In view to this, it has been observed that in Africa as the rural population increase and urbanisation sets in, the possible ramifications will be intensification of agriculture, expansion of the cultivated land, changes in social relations and economic diversifications amongst other changes [11], [14], [22]. Around the eastern slopes of Mount. Kenya virtually all these changes have occurred affecting the complex agricultural system of the communities living in this region. Major crops such as maize, tea and coffee have been the traditional crops widely grown by communities in this region with tea and coffee being key export cash crops for a long time; however the intensity of its cultivation has declined owing to climate change and unstable world markets. As a result, many farmers are abandoning coffee and tea farming for high valued horticultural crops. Individual and contracted farmers are producing for export or local markets. This paper focuses on land use intensification and diversification as adaptation strategies used by horticultural farmers in this region. These strategies are assumed to have direct effects on household livelihoods, land use and food security. The study sought to address the following three objectives:

a Find out the impact of agricultural intensification on household food security.

b Understand the re-emerging gender roles amongst horticultural farmer families.

c Examine land management practices embraced to reduce climate change farming risks.

\section{Data and Method}

Data used in this study was gotten from field work surveys carried out between $8^{\text {th }}$ February 2016 and $14^{\text {th }}$
March 2016 on 69 households randomly selected from the five counties within eastern slopes of Mount Kenya horticultural region block. To identify segments of farmers to participate in the study, snow balling technique was found relevant to help get farmers engaging in contract farming, local market supplies and export international market. Data was collected through focused group discussions, key informant interviews, participatory observation and semi-structured questionnaires. The questionnaires were completed through interviews with the farmers and covered household organisation structure, horticultural crops grown, income generated and land management practices. Stratified random sampling was applied to select land tenure types and households to participate in the study. Purposive sampling was then used to pick farmers from the sampling frame of all the five counties of Nyeri, Kirinyaga, Embu, Tharaka-Nithi and Meru counties. All sampled farmers practiced horticulture farming on freehold plots with some specializing in vegetables, fruits and tubers. For each household surveyed, the sampled families was geo-referenced using a Trimble 3D Global position system receiver to assist integrate location data with the gathered household data from the surveys. The mapped geo-referenced field data showed that in Mt. Kenya East region, most families live on or near the plots they own and practise horticultural farming. Multiple data sources and analytical methods were used in this study due to diverse horticultural production systems undertaken in this region. In the field survey, respondents were asked particular questions regarding to farm production levels, land size, food security and social networks. Secondary data was also used to evaluate the contribution of political, demographic and economic factors to the current state of affairs in the region.

\section{Results and Discussion}

\subsection{Agricultural Intensification and Household Food Security}

Many households were diversifying their agricultural systems by integrating horticultural crops with livestock and subsistence crops [43]. Intensive agricultural land use systems in this region were attributed to the increasing adoption of short duration horticultural crops and use of irrigation to maintain production throughout the year (Table. 1). Owing to the relatively small parcels of lands on average one to three hectares per farmer, fragmentation was common as farmers bought or leased parcels in different agro-ecological zones particularly within TeaDairy Zones (LH 1). Slightly over $54 \%$ of the interviewed farmers agreed to hiring farms in humid zones where they grew horticultural crops especially the contracted farmers. The move has intensified land utilization and cushion against climate-related crop failures [1], [4]. Based on the surveys and fieldwork, most households depended on horticulture farming for income generation. Food shortage 
was not common amongst interviewed households because many of these families also cultivated subsistence crops like maize, beans and sweet potatoes in small plots in the neighbourhoods. The region has many open air food markets where most farmers sold their horticultural produce and sourced the food they needed. The fact that most of the horticultural crops have ready market in nearby urban centers had led to engagement of many households in this fresh fruits and vegetables farming. Another emerging form of agro-based diversity noted observed in this region was keeping of improved dairy cattle as a source of food and off-farm household income. Horticultural farming is a lucrative investment in this region embraced by both old and young people, employed and non-employed folks as it contributed to direct wealth (Table 2).

Table 1. Common Horticultural crops grown.

\begin{tabular}{llll}
\hline Crop type & Market & Mode of Production & Why produce? \\
\hline Fruits & Local and Export & Irrigation & Income and consumption \\
Vegetables & Local and Export & Irrigation and Rain fed & Income and consumption \\
Tubers & Local & Rain fed & Income and consumption \\
\hline
\end{tabular}

Source: Author (Field survey)

Table 2. Income accruing from horticulture farming based on household characteristics (Estimates by respondents).

\begin{tabular}{lll}
\hline Land Size(Ha) & Annual Income(K. shs) & $\begin{array}{l}\text { Family members in } \\
\text { House hold }\end{array}$ \\
\hline $0.5-2.0$ & $<120,000$ & $2-7$ \\
$2.1-4.0$ & $120,000-230,000$ & $3-10$ \\
$4.1-6.0$ & $120,000-350,000$ & $3-12$ \\
$6.1>$ & $120,000>$ & $2-4$ \\
\hline
\end{tabular}

Source: Author (Field survey)

Climate change has introduced micro-environmental changes in production systems with observed variations being on the types of crops and agricultural land use practices in this surveyed areas. Notable effect was increasing land use diversification as farmers grew multiple crops on the fragmented plots. For horticultural production it was found out that the costs of production was increasing due to more water used for irrigated farming, low yields and erratic droughts reported by the interviewed households. As told by one farmer during an interview, "We are spending a lot of money on pesticides and water for these French beans due to the changing patterns of rains in this area", horticultural produce business is now an expensive affair only managed by those with financials to keep the irrigation taps running.

Most farmers in this region have adopted on farm climate change response practices such as changing crop type and diversification. These finding are in agreement to the results of related studies by Bryan, E et al [3], Howden, S., et al [7] and Schlenker, W. \& Lobell, D. B [16]. The findings ascertain that there is a transformation of traditional subsistence and cash crops agricultural production systems to high valued horticultural crops. More than $68 \%$ of the surveyed households engaged in fruits, vegetables and tubers cultivation. Other studies have suggested that farmers with access to irrigation are shifting to high value crops as a way of coming out of poverty [10], [11].

\subsection{Gender Roles in Horticultural Produce Farming}

In agricultural production women are engaging in multiple livelihood strategies both in male and female headed households. Due to the structural transformations taking place in the country, gender rule has been given prominent recognition with increased involvement of women in all levels of development and decision making [44]. In a male dominated occupation, women are now engaging in agricultural practices as farmers, traders, food processors and in labour markets [15]. The role of women in horticultural production within Mt. Kenya region is cross cutting ranging from farm level production, marketing to processing. In this particular case study, women were mainly involved in labour provision, value addition activities, marketing and production. Formation of social networks through farmer associations intensified income generating activities among the sampled households. The study established increased livelihood diversification strategies amongst women engaged in horticultural produce value chain through involvement in non-farm enterprises (Table. 3).

Table 3. Social organisation of horticultural producing households.

\begin{tabular}{llll}
\hline Marital Status & Occupation & Organisations & Importance of Social networks \\
\hline Married & Farming & Farmer Clubs & Market Information sharing, Loans \\
& Business & Self Help groups & \\
\hline
\end{tabular}

Source: Author (Field survey)

Although in most households both wife and husband were involved in horticultural production there were differentiated roles for men and women. Men controlled decisions relating to what to produce, inputs as well as how to spend the accruing income. Women on the other hand were involved in mobilization of labour from their families or neighbourhood, taking the harvested produce to the markets, attending farmer clubs and tending to other household duties. However, young women were mostly involved in horticulture and seemed knowledgeable on issues relating to market prices, demand 
trends and preferred horticultural crop varieties in the markets compared to their old female counter parts.

\subsection{Land Management Practices and Climate Change Adaptation}

In the wake of increasing global environmental changes such as climate change and droughts, horticultural farmers around Mount Kenya region are embracing land use practices which ensure continued productivity. Intensification of the current agricultural systems especially through horticultural farming has resulted to declining soil fertility and low yields. The basic onfarm management practices carried by most farmers were intercropping, growing of multipurpose crops and use of efficient irrigation techniques. Given the diverse agro-ecological zones in this region, different practices have been embraced to mitigate the effects of climate change such as land use change, use of green house technologies and even farmland land preservation initiatives like crop rotation[5], [9].

\section{Conclusion}

Horticultural farming in Mt. Kenya East region has undergone tremendous changes from coordination, organisation to production. The re-alignment of Kenya's agricultural sector has created more space for horticultural development. The ripple effects have been increased horticultural export trade, increased farmer ratios and efficient supply value chain systems. At the household level, horticultural land use intensification has increased significantly with complete re-alignment of men and women gender roles. Women's place has shifted to production and marketing in the supply value chain while men are involved in farm level organisation and headship responsibilities. More households are engaging in horticultural farming as a business and a diversification activity. Although most households engaged fully in horticultural production, some had alternative cash crops like tea, coffee and improved dairy farming. Women were pro active as key decision makers in both female headed and male headed families. Subsistence farming is still done around home stead in line with the horticultural calendar. The diverse food crops grown are consumed by the households and more often supplemented with fresh vegetables and fruits grown or sourced from the local markets. Food shortage is not common among the practicing farmers because of steady income from the horticultural farming business which is used to procure foodstuffs and consumables from the markets. Land management practices especially land uses are changing due to population pressure and climate change related adaptation measures. Cutting across the diverse agro-ecological zones in the region, farmers embraced irrigation, crop rotation and land fragmentation as climate change risk adaptation strategies. Emerging concerns for horticultural production in this region are the rising unsustainable soil and water resource management practices. This is attributed to declining resource quality as agro chemicals are increasingly used in horticultural farming practices. Moving forward, there is a need to profile small scale horticultural farmers in the different sub regions of Mt. Kenya area to appraise resource use as well as assess farmers support service needs. Alternative ways of including small holder horticultural farmers into the export market value chain should be explored given the many standards and Good Agricultural Practice (GAP) compliance requirements for such products.

\section{References}

[1] Alec Sithole and Cyril T. F. Murewi (2009) Climate variability and change over southern Africa: impacts and challenges. African Journal of Ecology, 47(1), 17-20.

[2] Baltenweck, I., Staal, S., Ibrahim, M. N. M., Herrero, M., Holmann, F., and Jabbar, M., (2003). Crop-livestock intensification and interactions across three continents: Main report. System-wide Livestock Program (SLP) project on trans regional analysis of crop-livestock systems. Nairobi, Kenya: ILRI. p. 118.

[3] Bebe, B. O., Udo, H. M. J., Rowlands, G. J., and Thorpe, W. (2003). Smallholder dairy systems in the Kenya highlands: breed preferences and breeding practices. Livestock Production Science, 82: 117-127.

[4] Bryan, E., Silvestri, S., Ringler, C., Herrero, M., and Okoba, B., (2013). Adapting agriculture to climate change in Kenya: Household strategies and determinants. Journal of Environmental Management 114: 26-35.

[5] Bryan, E., Deressa, T., Gbetibouo, G., and Ringler, C., (2009). Adaptation to climate change in Ethiopia and South Africa: options and constraints. Environmental Science and Policy, 12 (4).27-38

[6] Chamberlin, J.(2013). Market Access and Smallholder Development in Kenya and Zambia. Unpublished $\mathrm{Ph}$. D. Dissertation, Agricultural, Food and Resource Economics Department, Michigan State University, East Lansing, Michigan.

[7] Chelang'a, P. K., Obare, G. A and Kimenju, S. C (2013). Analysis of Urban Consumers' Willingness to Pay a Premium for African Leafy Vegetables (ALVs) in Kenya: a Case of Eldoret Town. Food Security, 5 (4), 591-595.

[8] Conelly, W. T. (1994). Population pressure, labor availability, and agricultural disintensification: the decline of agriculture on Rusinga Island, Kenya. Human Ecology, 22(2): 145-170.

[9] Conelly, W. T., and Chaiken, M. S. (2000). Intensive farming, Agro-Diversity, and Food Security under Conditions of Extreme Population Pressure in Western Kenya. Human Ecology, 28(1) 19-51.

[10] Constitution of Kenya. (2010). The Constitution of Kenya. Nairobi. Government printer.

[11] Dannenberg, P. and Nduru, G. M. (2015): Regional Linkages in the Kenyan Horticultural Industry. - In: Dannenberg, P. \& Kulke, E. (eds.), Economic Development in Rural Areas: Functional and Multifunctional Approaches, p. 15-34. Ashgate Publishing, Farn ham.

[12] Dannenberg, P., Kunze, M. and Nduru, G. M. (2011): Isochronal Map of Fresh Fruits and Vegetable Transportation from the Mt. Kenya Region to Nairobi. Journal of Maps,7: 273-279. 
[13] Dannerberg. P, and Nduru Gilbert. M., (2012). Practices in international value chains: the case of the Kenyan fruit and vegetable chain beyond the exclusion debate. Royal Dutch Geographical Society, 104: 41-56.

[14] Godfray, H. C. J., Beddington, J. R., Crute, I. R., Haddad, L., Lawrence, D., and Muir, J. F. (2010). Food security: the challenge of feeding 9 billion people. Science, 327: 812-818.

[15] Government of the Republic of Kenya. (2012.) Vision 2030 Development Strategy for Northern Kenya and the Arid Lands. Retrieved from http://www.disaster risk reduction.net.pdf. Accessed on July 20, 2013.

[16] Howden, S. M., Soussana, J. F., Tubiello, F. N., Chetri, N., Dunlop, M., and Meinke, H., (2007). Adapting agriculture to climate change. Proceedings of the National Academy of Sciences 104 (50), 19691-19696.

[17] Jaetzold, R., and Schmidt, H.,(1982). Farm Management Handbook of Kenya. Volume II. Parts A, B and C. Ministry of Agriculture in Cooperation with German Agency for Technical Cooperation, Nairobi.

[18] Jätzold, R., Schmidt, H., Hornetz, B. and Shisanya, C. (2006): Farm Management Handbook of Kenya. Vol. II: Natural Conditions and Farm Management Information, Part C: East Kenya, Subpart C 1, Eastern Province: 571 S., Nairobi.

[19] Jenkins, S (2012). Ethnicity, violence, and the immigrantguest metaphor in Kenya. Africa Affairs 111 (445), 576-596.

[20] Jianhua He a, b, Yaolin Liu a, b Yan Yu c, Wenwu Tang d, e, Weining Xiang d, f, and Dianfeng Liu., (2013). A counterfactual scenario simulation approach for assessing the impact of farmland preservation policies on urban sprawl and food security in a major grain-producing area of China. Applied Geography 37: 127-138.

[21] Jin, S., and Jayne, T. S. (2013). Land rental markets in Kenya: implications for efficiency, equity, household income, and poverty. Land Economics, 89 (2), 246-271.

[22] Kanyinga, Karuti (2009). The legacy of the white highlands: land rights, ethnicity, and post-2007 election violence in Kenya. Journal of Contempary African Studies. 27 (3), 325344.

[23] Kibetu, D. K, Nyaga. P, Mwangi. J. M and Muchiri. D (2015). Analysing the Dynamics of Spatial Interaction and SocioEconomic Transformations around Chuka University, Main Campus Using Remote Sensing and GIS Techniques in the proceedings of the 2nd International Chuka university Research conference, 28-30th, October 2015, Chuka.

[24] Krishna, A., Kristjanson, P., Radeny, M., and Nindo, W. (2004). Escaping poverty and becoming poor in 20 Kenyan villages. Journal of Human Development, 5(2), 211-226.

[25] Kristjanson, P., Mango, N., Krishna, A., Radeny, M., and Johnson, N. (2009). Understanding poverty dynamics in Kenya. Journal of International Development 22 (7), 978-996.

[26] Lambin, E. F., Geist, H. J. \& Lepers, E. (2003): Dynamics Of land-Use And land-Cover change In tropical regions. Annual Review of Environment and Resources 28: 205-241.

[27] Little, P. D., K. Smith, B. A. Cellarius, D. L. Coppock and C. B. Barrett (2001) Avoiding Disaster: Diversification and Risk Management among East African Herders. Development and Change.,33 (3), 401-433.
[28] Marcia., M. C, Maria., I. M, and S. G. Hallett. (2016). Market Barriers Faced by Formal and Informal Vendors of African Leafy Vegetables in Western Kenya. Journal of Food Distribution Research ,47 (I3), 49-60.

[29] McCord, P. F., Cox, M., Schmitt-Harsh, M. and Evans, T. (2015): Crop diversification as a smallholder livelihood strategy within semi-arid agricultural systems near Mount Kenya. Land Use Policy, 42: 738-750.

[30] McCulloch, N. \& Ota, M. (2002): Export horticulture and poverty in Kenya: IDS Working Paper 174: 1-34, Brighton (Institute of Development Studies).

[31] Mithöfer, D., E. Nang'ole \& S. Asfaw (2008), Small holder Access to the Export Market: The Case of Vegetables in Kenya. Outlook on Agriculture, 37: 203-211.

[32] Muyanga, M. \& Jayne, T. S. (2014): Effects of rising rural population density on smallholder agriculture in Kenya. Food Policy, 48: 98-113.

[33] Mwangi, T. (2008), Impact of Private Agrifood Standards on Smallholder Incomes in Kenya. Nairobi: Kenya Horticultural Development Programme.

[34] Neven, D., M. M. Odera, T. Reardon, and H. Wang. (2009). "Kenyan Supermarkets, Emerging Middle-Class Horticultural Farmers, and Employment Impacts on the Rural Poor." World Development 37 (11), 1802-1811.

[35] Ouma, S. (2010), Global Standards, Local Realities: Private Agrifood Governance and the Restructuring of the Kenyan Horticulture Industry. Economic Geography, 86: 197-222.

[36] Pearce, J., Ngwira, A., Chimseu, G., 1996. Living on the Edge. Save the Children UK, London.

[37] Porter, G. (2007): Transport planning in sub-Saharan Africa. Progress in Development Studies7: 251-257.

[38] Schlenker, W., Lobell, D. B., (2010). Robust negative impacts of climate change on African agriculture. Environmental Research Letters,5 (1).

[39] Slaymaker, O., Spencer, T., \& Embleton-Hamann, C. (2009). Geomorphology and global environmental change. New York: Cambridge University Press.

[40] The Kenya Food Security Steering Group (KFSSG) (2008). "The Impact of Rising Food Prices on Disparate Livelihood Groups in Kenya." Retrieved from http://documents.wfp.org.pdf.Accessed JUNE 22, 2013.

[41] Tilman, D., Balzer, C., Hill, J., \& Befort, B. L. (2011). From the cover: global food demand and the sustainable intensification of Agriculture. Proceedings of the National Academic of Sciences, 108: 20260-20264.

[42] Van de Steeg, J. A., Verburg., P. H, Baltenweck, I and Staal., S. J (2010). Characterization of the spatial distribution of farming systems in the Kenyan Highlands. Journal of Applied Geography,30: 239-253.

[43] Waitathu, N. (2008), Kenyan Horticulture: Weathering the Political Storm? New Agriculturist. Available at http://www.new-agri.co.uk. Accessed on 24th April 2009.

[44] Willkomm, M., Vierneisel, B and Dannerberg. P (2016) Land use change dynamics in the Mt. Kenya region: a remotely sensed analysis using Rapid Eye satellite images. Zbl. Geol. Paläont. Teil I, 1: 23-40. 